\title{
RAD23A Gene
}

National Cancer Institute

\section{Source}

National Cancer Institute. RAD23A Gene. NCI Thesaurus. Code C106249.

This gene is involved in both nucleotide excision repair and the regulation of protein degradation. 